\title{
The Fruits of Dissent and the Operationalization of Faith: A Midrashic Reading of the Akedah
}

\author{
Elliot Lyons
}

\section{1 \\ Introduction}

The Bible is a text fraught with 'gaps' - narrative silences, inconsistencies, and places where questions arise - and as such yearns to be interpreted. Genesis 22, Abraham's intended sacrifice of Isaac, the Akedah ('binding') as it is known in Judaism, is nothing but exemplary in this regard. The biblical text maintains two 'gaps' ${ }^{1}$ where Midrash - biblical interpretation in the Jewish tradition which juxtaposes biblical passages - places Satan into the narrative in a manner that emphasizes the fortification of faith through interrogating its very premises. ${ }^{2}$ The more questions put to Abraham, in other words, the deeper his faith becomes.

Accordingly, this chapter will begin by locating the two main 'gaps' in the text: Genesis 22:1, where Abraham was tested "after these things/ words", and the narratological gap between verses three and four. In presenting the textual gaps, I will use traditional historical-critical exegesis in order to juxtapose the radical potential and imagination present in Midrash to a method of interpretation that either entirely fails to answer the gaps, or only glimpses the tip of the theological iceberg that is the Akedah. Next I will discuss three Midrashim, from Genesis Rabbah (GR), from Midrash Tanhumah Yelammedenu (TY), and from the Babylonian Talmud (BT), which reconsider the gaps from the first half of the chapter in light of Satan questioning the ethics of a sacrifice-forged faith, and God pressing the grim task of filicide.

1 There is another 'gap' between the end of chapter 22 and the beginning of chapter 23, where Abraham returns and finds Sarah dead. This issue will not be dealt with here due to space restrictions and thematic inconsistency.

2 I am heavily indebted to Daniel Boyarin, who is also responsible for the notion of 'gaps', and Gary Porton for this rendering of Midrash. Cf. Daniel Boyarin, Intertextuality and the Reading of Midrash (Bloomington: Indiana University Press, 1994); Gary G. Porton, Understanding Rabbinic Midrash (Hoboken: KTAV Publishing House, 1985). My article is an elaboration of my master thesis written under the aegis of prof. dr. Marcel Poorthuis (University of Tilburg).

(C) ELLIOT LYONS, 2017 | DOI 10.1163/9789004335530_020

This is an open access chapter distributed under the terms of the CC BY-NC 4.0 licenselot Lyons - 9789004335530 
Here is the biblical text of Genesis 22:1-5:

Some time afterward, God put Abraham to the test.

He said to him, 'Abraham,' and he answered, "Here I am."

And He said, 'Take your son, your favoured one, Isaac, whom you love, and go to the land of Moriah, and offer him there as a burnt offering on one of the heights that I will point out to you."

So early next morning, Abraham saddled his ass and took with him two of his servants and his son Isaac. He split the wood for the burnt offering, and he set out for the place of which God had told him. On the third day Abraham looked up and saw the place from afar.

Genesis 22 begins easily enough with, "Some time afterward, God put Abraham to the test." ${ }^{3}$ Here, the issue is the interpretation of the Hebrew text:

ויהי אחר הדברים האלה והאלהים נסה את אברהם

(wajehi achar haddevarim ha'ele wehaElohim nissah et Avraham).

And specifically the terms, 'דברים', (devarim) 'speeches', 'occurrences', 'things', 'נסה', (nissah, < nasah) to 'try', 'test', or 'prove', and 'האלהים', (haElohim) or 'the God'. For example, דברים (devarim) is not translated in the Jewish Publication Society (JPS) translation and in the Dutch translation Nieuwe Bijbel Vertaling, while the New Revised Standard Version translates the term as 'things', along with the King James Version. The main question or gap here is what preceded Genesis 22:1, because the sentence suggests that what came before is intimately related to the opening text. Traditional historical-critical commentary will be applied to this question below.

\subsubsection{Gordon J. Wenham's Misdirection}

Traditional biblical commentaries furnish us with answers to the literary function of the phrase and the impossibility of identifying the precise events preceding Genesis 22:1. Gordon J. Wenham assesses the opening statement as being a:

3 The Jewish Publication Society (JPS). All biblical translation will come from this source, unless otherwise noted. 
[G]reat moment, both from a dramatic and a theological perspective. It serves to cushion the listener from the full impact of the horrific command to Abraham, and it diverts attention from the question whether Isaac will be sacrificed to whether Abraham will stand up to the test. ${ }^{4}$

While admitting the theological import of the phrase, he fails to identify the events that underscore said import. However, he does touch upon the potential (mis)direction of attention from Isaac to Abraham in order to make the death sentence seem less horrific. Wenham believes listeners are spared the full impact of the command because Genesis 22:1 shifts emphasis from the content of the command - Isaac being sacrificed - to its form: That a command was given by God, and as such should be obeyed.

However, this interpretation itself is misleading because questioning whether Abraham will carry out the command cannot be seen as separate from the content - sacrificing Isaac - owing to the relationship between Abraham and Isaac. Hence shifting attention from Isaac to Abraham only leads back to Isaac, underscoring the horrific consequences of the command. Still, (mis)direction remains a key element of the narrative, as will be seen in the Midrashim, where Satan's (mis)direction pierces the heart of Abraham's dilemma.

\subsubsection{Victor P. Hamilton's 'Lad'}

Victor P. Hamilton gives another interpretation of the verse when he claims that it is impossible to know the identity of the preceding events referred to in verse one, concluding that the timespan is most likely years because Isaac does not seem to be a newborn. Abraham refers to Isaac as a 'lad' or na'ar in verse five, a term which would suggest that Isaac is not a fully-grown man. ${ }^{5}$ It almost seems as if Hamilton dismisses the preceding events - marking them as insignificant - because they cannot be known in any concrete manner; it is precisely this dismissal that is concretized in Midrash.

\subsubsection{Hamilton and Wenham: God tested Abraham}

A curious use of language in Genesis 22:1 is the formulation of 'the God' (האלהים) in relation to 'test' (נסה), which has implications on how the gap in the text posed by "after these things" is read. This is a strange formulation due to the

4 Gordon J. Wenham, Genesis 16-5o, Word Biblical Commentary Vol. 2 (Dallas: Word Books, 1994), 103.

5 Victor P. Hamilton, The Book of Genesis: Chapters 18-50, The New International Commentary of the Old Testament (Grand Rapids: William B. Eerdmans Publishing Company, 1995), 100. 
'the' before God, as if the text is trying to distinguish God in some manner regarding the testing. Both Hamilton and Wenham note the bizarre inclusion of 'the' before Elohim, with Hamilton remarking 'the' ensures that the order is coming from none other than God himself. ${ }^{6}$ Furthermore, he goes to great lengths proving it is God who is appropriately testing Abraham, by comparing the verse to Exodus 15:25, the next instance where God appears as the subject, and Exodus 20:20. ${ }^{7}$

Hamilton's analysis deals with the tension in the text - why God would assign such a horrible task - and does away with it through a normative understanding of faith: God could not possibly do anything inappropriate or uncalled for, and therefore, by virtue of the command being given, it must be just, and even good. However, if God's test is to be appropriate, then what did Abraham do to deserve such a fate? How is ordering the slaying of an innocent son by a righteous father in any way ethical? Can blind obedience be the answer? This piece of exegesis also brings to the surface concerns about how to categorize 'good', and whether or not these categories can apply to God at all. It is clear in Hamilton's analysis that the text - "the God tested" - has the mark of Satan all over it, for Satan is normally associated with such cruel acts. Yet it is the God who tests. Where Hamilton falters by explaining away the tension, Midrash makes its stand in this very tension by inserting Satan who prompts God to test Abraham, engaging the thoughts that arise when God does the inexplicably cruel.

Wenham provides another viewpoint by characterizing the Elohim as the persona God assumes when He desired to distance himself from his actions. ${ }^{8}$ Through the juxtaposition of names, Wenham voices, just as Hamilton, nearly inescapable thoughts and feelings in the contradiction between perceptions of God's justice and his present actions - cruel and confounding. However, just as quickly as he begins to unravel the thread of meaning, similarly to Hamilton, he cuts the thread by not seeking out what constitutes the individual threads that compose the string. God may be acting remotely, and this just may be marked by the use of Elohim, but why would God choose to act in this manner? What would He be attempting to prove? Wenham remarks נסה - 'test',

6 Hamilton, The Book of Genesis, 100.

7 For Hamilton, the two instances are similar because God is doing the testing. When a human being is the subject of the verb, or testing, and God is the object, Hamilton categorizes the testing as negative, being "uncalled for, and out of place." In Exodus 20:20, God is doing the testing and some form of nasa (to test) is being used for evidencing fear of God. Hamilton, The Book of Genesis, 101.

8 Wenham, Genesis 16-50, 103. 
'prove', 'tempt' or 'try' - is used to show a person's true character, generally in the face of hardship, ${ }^{9}$ but what purpose does such a test have in Genesis 22 ? What does it prove, and to whom? Moreover, what was the temptation? Was it Abraham's love of Isaac, and to overcome this love in the face of divine commandment? Or was it to test whether Abraham would follow such a cruel and senseless order just because God commanded it?

The gaps in the text are already numerous in the opening words of Genesis 22, being present in the language - 'test' and the God - and the language which narrates absence, as in the case with claiming that the command came "after these things". The biblical commentaries are useful in so far as they begin to unearth kernels of information that send our minds spiralling down a path towards an answer, but they fail to supply that level of imagination that will push the limits of what can be said theologically about faith, due to being bound by the conventional exegetical method.

Yet, "after these things/words", whatever they were, Abraham is asked by God to take his son and offer him up as a burnt offering at a place that God will show him. ${ }^{10}$ Responding to the call, Abraham rises early the next morning, enlisting two of his servants as well as his donkey to accompany him and Isaac. He also splits wood for the fire, and with this last preparation, he sets their feet to the road, and so ends verse three. Verse four begins two days after the beginning of the journey, "On the third day." This is where the next gap comes into sight.

\subsection{Gap 2: Three Days of Silence}

The biblical text gives no hint about what occurred during the walk that has lasted almost three days. However, it does identify that Abraham and his retinue are at a place where they can see the mountain on which he is to offer up Isaac. Needless to say, curiosity is piqued by this omission of details: If they had been travelling for two days, why were they still so far away on the third day? Did something impede their progress? What did they talk about? Or were they, as the text and also Hamilton in his commentary on the gap suggest, ${ }^{11}$ silent and speechless?

Hamilton and Wenham give similar answers to the gap between verses 22:3 and 22:4. Hamilton notes that the expression "on the third day" is the Hebrew equivalent of "at the eleventh hour". ${ }^{12}$ Wenham remarks that three days is

\footnotetext{
9 Wenham, Genesis 16-5o, 104.

10 Genesis 22:2.

11 Hamilton, The Book of Genesis, 107.

12 Hamilton, The Book of Genesis, 107.
} 
a typical period of preparation for something important, also noting that Abraham was most likely filled with anxiety and dread. ${ }^{13}$ Although Wenham puts into words what is undoubtedly on the minds of readers - Abraham being anxious at the prospect of having to sacrifice his son - he leaves no further comment on this most interesting issue of Abraham's feelings. The Midrash, on the other hand, gives us a situation where Abraham's anxieties are manifestly present before him in the form of Satan, leaving him to confront his fears and anxieties about having to sacrifice his beloved son.

After the events on the mountain - the building of the altar, the binding, the retaining of Abraham's hand by the angel because he had not withheld Isaac from the Lord, the blessing given to Abraham - and his journey to Beersheba, the chapter comes to a close.

\section{$3 \quad$ Satan's Akedah and the Process of Faith}

The foregoing concentration on the gaps in the text acts as a beginning point in both the interpretation of the biblical text and the concurrent process of Abraham's journey towards faith, a process which is brought out in the Midrash. The three Midrashim presented below - from the Babylonian Talmud ${ }^{14}($ вт), from Genesis Rabbah ${ }^{15}$ (GR), and from Midrash Tanhuma Yelammedenu ${ }^{16}(T Y)$ deepen the biblical text through inserting Satan into the narrative gaps, in a

13 Wenham, Genesis 16-50, 106-07.

14 The word Talmud is derived from lamad, 'to study'. This text was still being developed throughout the fifth century of the Common Era. Cf. Moses Mielziner, Introduction to the Talmud (New York: Bloch Publishing Company, 1968).

15 The Genesis Rabbah, or Bereshit Rabbah, achieved its final form circa $45^{\circ} \mathrm{CE}$, being a Midrash collection composed of a verse-by-verse analysis of the book of Genesis. Cf. Jacob Neusner, "Genesis in the Genesis Rabbah," in The Encyclopedia of Midrash: Biblical Interpretation in Formative Judaism Vol. I (eds Jacob Neusner and Alan J. Avery Peck; Leiden: Brill, 2005).

16 This Midrash collection derives its title from the opening formula that precedes the main text: “Thus began R. Tanhuma bar Abba." However, R. Tanhuma did not author these texts. Rather it is thought that he may have laid the groundwork in the latter half of the fifth century CE for the text that would later bear his name. A definitive dating of the text, or any of the Tanhuma homilies for that matter, is not possible, while the place of origin is not certain either. "Introduction," in Midrash Tanhuma-Yelammedenu: An English Translation of Genesis and Exodus from the Printed Version of Tanhuma-Yelammedenu with an Introduction, Notes, and Indexes, trans. Samuel A. Berman (Hoboken: KTAV Publishing, 1996). Cf. Myron B. Lerner, "The Works of Aggadic Midrash and the Esther Midrashim," in The Literature of the Sages Vol. II (ed. Shmuel Safrai; Assen: Von Gorcum), 169-70. 
way that questions the nature of the relationship between God, Satan, faith, and Abraham, and the normative conceptions of each. In other words, the process of faith is its interrogation, asking the difficult questions. Through the texts, we will find the truth in lies and the ugliness of truth, and we will notice that sacrifice may be but a canvas on which these concepts are painted, construing spirituality as a process in which Satan plays a positive role. The texts will be treated synchronically because Satan's character remains the same throughout - knowledgeable, sensible, surly - which makes them effective for discerning a general rabbinic opinion on Satan's character. By treating the texts synchronically, each Midrash is a revision of the biblical text, and when read together they create a new narrative.

We will start at the beginning of the tale and work our way through the two gaps, mirroring the structure of the previous section. The first gap - "after these things" - will be analyzed using the BT and GR, which prepares the critical theological questions regarding God's truth and justice Abraham must deal with in the second gap - three days of silence - where Satan comes to Abraham and Isaac, forcing them to confront the implications of these theological issues.

\subsection{Gap 1: The Midrash on "After these Things"}

The Babylonian Talmud furnishes us with a conversation where God bets with Satan that should he require Isaac, Abraham would not withhold him, thus filling in the gap in Genesis 22:1 with a wager. 'After these things' is here interpreted as 'after these words'. Which words? The conversation between God and Satan. The conversation begins with Satan flattering God, conveniently contrasting God's graciousness at giving Abraham a child at the age of one hundred to Abraham's ungratefulness at failing to provide a sacrifice at Isaac's weaning:

Sovereign of the Universe! To this man didst Thou graciously vouchsafe the fruit of the womb at the age of a hundred, yet of all that banquet which he prepared, he did not give one turtle-dove or pigeon to sacrifice before thee. ${ }^{17}$

God replies that should he require Isaac, Abraham would obey.

Satan gives the Sovereign of the universe due recognition, contrasting the gift - a miracle - that he gave Abraham and Sarah to Abraham's failure to offer

17 вт Sanhedrin 89b, translation in The Babylonian Talmud (ed. Rabbi Dr. I. Epstein; London: Soncino Press, 1935), 595 . 
the paltriest of offerings at Isaac's weaning - a turtledove and pigeon, which would have had no intrinsic value to Abraham, unlike Isaac who is the earthly manifestation of Abraham's pact with God and God's faithfulness to Abraham. ${ }^{18}$ Accordingly, Satan recognizes that one can only sacrifice what one esteems, and what would be more highly esteemed than Isaac, a miracle? Yet, at the same time, Satan could be chastising Abraham for forgetting an offering as meagre as a turtledove and pigeon, underscoring the importance of the offer, even if it is not equal to what was given. Hence Satan's emphasis is on the sacrifice, which contrasts to Wenham's earlier remarks where the purpose of the first verse was to direct the listeners' attention away from the sacrifice.

God, on the other hand, confidently and seemingly plays into Satan's hands through placing the wager. If God knows Abraham is faithful, it would indeed be cruel to give such a test, particularly to bolster his ego and show off his star pupil. Moreover, even if God was punishing Abraham for a failed sacrifice, the punishment given rather befits a tyrant than a just, merciful and forgiving God. This incongruity leads us to pose the same question again, this time with the new information provided by the $B T$ : Why would God place such a bet? Seeking to understand the text, this Midrash asks questions of the biblical text in order to foster understanding through the mouth of Satan. Hence, although the gap is 'filled' by a specific answer, "a wager", the overall theological question still needs refinement. Next, we move to $G R$ where a reason is given for the test: "So that the world may know the truth."

\subsubsection{Genesis Rabbah: Abraham as God's Banner of Faith}

The following passage uses the term נסה (nasa) which, as stated earlier, is not only a test but also an event that proves the mettle of the individual being tested. Here Abraham stands as an example for truth, something which proves to be as enigmatic as faith:

And it came to pass after these things, that God did prove ('nissa') Abraham (Gen. 22:1). It is written, Thou hast given a banner ('nes') to them that fear thee, that it may be displayed ('le-hithnoses') because of the truth. Selah (Ps. LX, 6): This means, trial upon trial, greatness after greatness, in order to try them in the world and exalt them in the world like a ship's ensign [flying aloft]. And what is its purpose? Because of the truth. Selah: In order that the equity of God's justice may be verified in the world. Thus, if one says, "Whom He wishes to enrich, He enriches; to impoverish, He impoverishes; whom he desires, He makes king; when he wished, He 
made Abraham wealthy, and when He wished He made him a king", then you can answer him and say, "Can you do what Abraham did?" Abraham was a hundred years old when his son Isaac was born unto him (Gen 22:5); yet after all this pain it was said to him, take now thy son, thine only son (Gen 22:2), yet he did not refuse. Hence, Thou hast given a banner to them that they fear thee, that it may be displayed; so it is written, that God did prove Abraham. ${ }^{19}$

Abraham endured even the annihilation of a miracle because he feared God, knowing that the truth is this very fear, or an awe that reveres and listens, echoing Psalm 6o:6 - "Give those who fear You because of Your truth a banner for rallying. ${ }^{20}$ The banner is itself the fear of God.

Similarly to the $B T$, God is cloaked in a cruel mysteriousness on account of his incomprehensible stance on justice. If God does what he wills, giving this name to justice and truth, then how can it be just to ask a largely innocent Abraham to commit filicide, going directly against God-given commandments? Is this his truth? Or is facing the death of Abraham's son, who was given to him at one hundred years old, ${ }^{21}$ by his own hands ${ }^{22}$ the price of faith? Could you do any of these things after being similarly blessed? And so the test began after these things; ${ }^{23}$ after having a son and the accompanying joy swept away. Hence, in GR, Hamilton and Wenham's issue of whether the command originates from God is not of central importance, but rather what the command says about how we think about God.

If the remarks from the $B T$ are considered as an answer to $G R$ - why would God place such a horrible wager? - then it seems God needs Satan in order to uplift Abraham to greatness, using him as an example for the world to see. Put simply, God is omnipotent, thus he could have acted alone, which leads to the question why Satan has a role in this. Wenham remarked "the Elohim" was used to distance God from the act, and here God is distant in that Satan spurs the test, and in doing so, bridges the gap between God and the command in a seamless manner. Yet at the same time God is still intimately involved in the events. Satan could possibly be one half of the same force, with the other half being occupied by God.

19 Genesis Rabbah 55:1, in Midrash Rabbah Vol. I, trans. Rabbi Dr. H. Freedman and Maurice Simon (London: Soncino Press, 1951), 482.

20 JPS. Note that the Midrash contains a wordplay: nissah ('prove'), nes ('banner', 'miracle').

21 Genesis 21:5.

22 Genesis 22:2.

23 Genesis 22:1. 
Considering the Midrashim surveyed so far and looking ahead to the proceeding texts, it could also matter not so much which 'side' - light or dark, good or bad and evil - that either of them occupies as the opposition existing in the first place. Stuck in the middle of this continuum is Abraham, who must navigate it in order to understand faith through confronting it, and questioning it, as will been seen in the Midrashim from the $T Y$ and $G R$ regarding the second gap where both Abraham and Isaac are confronted by Satan on the way to Moriah.

\subsubsection{Satan and the Road to Moriah}

We will deal with the unintended consequence of the faithful: Satan confronting Abraham in the Midrash Tanhuma Yelammedenu and Genesis Rabbah. $G R$ will not be given a separate subheading because it reiterates the same sentiment found in the $T Y$ - that Abraham will be labelled a murderer if he commits filicide - save that in the former text, Abraham, when pressed by Samael, ${ }^{24}$ confesses his intent to kill Isaac. In both texts, Abraham remains stalwart and faithful in having the consequences of his actions put plainly before him in a straightforward, confrontational manner.

Satan appears to Abraham as an old man in the $T Y$, inquiring about Abraham's destination. Abraham is going to pray, and Satan smugly retorts "[D]oes one carry fire and a knife in his hands, and wood on his shoulders?". ${ }^{25}$ Abraham needs the knife and wood to prepare food, but Satan cuts in, revealing his presence when God gave the command, and Abraham would be foolish to relinquish such a blessing:

Have you not heard of the parable of the man who destroyed his own possessions and then was forced to beg from others? If you believe that you will have another son, you are listening to the words of a seducer... And if you destroy a soul, you will be legally accountable for it. ${ }^{26}$

24 Louis Ginzberg gives this as an alternative name for Satan; Freedman, in his translation of Genesis Rabbah, marks Samael as a wicked angel, with the Dictionary of Deities and Demons giving Samael as a name given in the intertestamental period for the devil, who, among other things, is leader of the hosts of evil and persecutes the righteous. Louis Ginzberg, The Legends of the Jews, trans. Henrietta Szold (Philadelphia:Jewish Publication Society of America, 1937), 175; B. Becking, P. van der Horst, K. van der Toorn, eds, The Dictionary of Deities and Demons [DDD ] (Leiden: Brill, 1999), 468; Cf. E. E. Urbach, The Sages: Their Concepts and Beliefs Vol. I, trans. Israel Abrahams (Jerusalem: Magnes Press, 1975), 161-169.

25 Midrash Tanhuma-Yelammedenu Wayera 30a, 144.

26 Midrash Tanhuma-Yelammedenu 30a, 144. 
Satan unearths the legal ramifications of Abraham's actions through speaking common sense. Ironically, he warns Abraham for the seducer (Satan). He prepares Abraham for the idea that God may be fooling him, as if to ask, utilizing the themes from $G R$ above, yet refined, what type of truth involves contradicting the law? Abraham will be not only breaking the general prohibition against killing but also the law prohibiting child sacrifice in Leviticus 20:2:

Moreover, thou shalt say to the children of Israel: Whosoever be of the children of Israel, or of the strangers that sojourn in Israel, that giveth his seed unto Molech; he shall be surely put to death; the people of the land shall stone him with stones. ${ }^{27}$

Legally, according to Satan, Abraham will be held accountable, and this will most likely be through paying with his life; thus, although Satan does not refer to Leviticus 20:2, he certainly implies as much in his speech. Accordingly, listening to a voice that told Abraham otherwise would be foolish - seduction to a fault - and how can one possibly represent God's truth through filicide resulting in death? This would indeed be a grim fate.

In $G R$, Samael also confronts Abraham, pointedly asking, "What means this, old man! Hast thou lost thy wits? Thou goest to slay a son granted to thee at the age of a hundred!". ${ }^{28}$ Abraham cannot, in Kierkegaardian terms, be both in adherence and in violation with the law at the same time. Moreover, Samael averts, "To-morrow He will say to thee, Thou art a murderer, and art guilty". ${ }^{29}$ Satan further presses Abraham, asking him if he could withstand an even greater test, following this question with a quote from Job's friend, Eliphaz, "If a thing be put to thee as a trial, wilt thou be wearied?". ${ }^{30}$ This last question functions to precipitate further reflection on Abraham's behalf because it seeks after his motivations, which in turn asks after his values - is filicide a fair price for anything? Especially for something unknown? These questions could very well prove too heavy a burden; hence in $G R$ and the $T Y$, we find the weight of the questions becoming stronger as Satan himself speaks to Abraham.

27 JPS. The term 'Molech' has been argued to be a divine name as well as a technical term used in the cultic sacrifice of children. The Old Testament view on this cult of child sacrifice is that 'Molech' was predominantly a Canaanite practice, as is demonstrated in Deuteronomy 12:31 and 2 Kings 17:17, although it was practiced in Jerusalem. $D D D$, 1090-1097.

28 Genesis Rabbah 56:4.

29 Genesis Rabbah $56: 4$.

$30 \quad$ Job 4:2. 
The two Midrashim underscore and deepen the questions raised in the first 'gap' as to the nature of God, Satan, good, bad and evil. Satan argues the moral point of acting in accordance with the law, while God, in a Job-like distance, allows Satan to approach Abraham, and counter His orders - yet Abraham remains steadfast, rebuffing Satan. The key question here is the purpose of Satan, and the answer may be that Satan will aid Abraham in understanding why he believes and adheres, that is, the content of his faith, and not only the fact that he adheres unquestionably.

This is, of course, in spite of the fact that the rabbis did not view knowledge of the reasons for the commandments as necessary for following them; thus the commandments have merit apart from the motivations behind them. ${ }^{31}$ Yet, part of the purpose of the commandments is to benefit and keep people away from the evil inclination through testing, which makes one mindful of one's mistakes. ${ }^{32}$ However, in the end, none of this reasoning is needed to carry out a command. Thus, to use the language of Plato's Eutyphro, commandments are pious both because they are God-given and because of their intrinsic value. At every turn of thought we find a 'but', and we know from the $G R$ that Abraham is an exception, and the rule, who would obey because it is required. He must face Satan and his fear of failure without having the belief filicide will be recalled, believing with understanding through considering the contrary Satan's words, which very competently ask: What kind of God would require filicide? However, in all the texts surveyed, no hint of Abraham's inner process has been given, and he has faced Satan coolly, confidently.

A Mother's Love: Satan, Sarah, Isaac and Abraham in the Midrash Tanhuma Yelammedenu and Genesis Rabbah

The $T Y$ and $G R$ will be discussed together because both are built upon Satan noting Sarah's disgust at Abraham's actions, if only she knew, and Satan coming to Isaac to tempt him, disguised as a young man. In the latter text, Satan also mentions Ishmael, and Isaac breaks down in the face of Satan's word, causing Abraham to comfort him by telling him that if God does not provide an offering, Isaac will be the offering. These Midrashim add to the depth of the trial because both Abraham and Isaac admit and accept the truth that the former will sacrifice and the latter will be sacrificed.

In the $T Y$, Satan questions Isaac in the same manner as Abraham, with Isaac releasing that he is journeying to study law. "Alive or dead?" Satan inquires. ${ }^{33}$

\footnotetext{
$31 \quad$ Urbach, Sages, 368.

$32 \quad$ Urbach, Sages, 367.

33 Midrash Tanhuma-Yelammedenu 3oa, 144.
} 
Isaac responds by asking how one could possibly study law while dead, resisting Satan's attempt to tempt him away from his father's trust. Lastly, Satan relays that Sarah would be beside herself if she knew to what grim task this 'demented' man set himself, as if to say that death is a perverse tool for instruction. ${ }^{34}$ Like his father, Isaac accepts his fate by avowing fealty to his heavenly and earthly fathers.

Isaac, here, is faced with the reality of death. The $T Y$ also reveals that Abraham, to explain their departure, told Sarah he was to provide Isaac with critical instruction. ${ }^{35}$ Hence Satan confronts Isaac with the lies of Abraham, giving Isaac all the information he needs to make an informed decision himself, just as he did with reminding Abraham that he would be breaking the law. Similarly, in GR Samael calls on Isaac as the "son of an unhappy mother", telling him Abraham will kill him, and then asking him whether his inheritance would go to Ishmael, "the hated of her [Sarah's] house". ${ }^{36}$ Isaac cries out to Abraham, causing Abraham to shun Sammael and offer the strange comfort of telling Isaac that if God fails to provide an offering, Isaac will be the burnt offering - "so they went both of them together - one to slaughter and the other to be slaughtered". 37

In the text from $G R$, Samael forces Abraham to tell Isaac the truth, which is a bizarre comfort, in fact being the same comfort afforded Abraham in his relation to God: Both must have faith in their fathers as their only solace. With the same processes being mirrored between father-son and God-Abraham, a queer bond is made between all parties based in faith, and a new understanding of the role love plays in faith. Love requires sacrifice, which in turn requires sacrificing parts of the self. Consequently, this may be the 'instruction' Abraham told Sarah he would give Isaac in the $T Y$, and the truth Abraham uttered along with this lie - for how can one be instructed and study law while dead? Moreover, faith could be rendered here as Abraham and Isaac submitting to the reality of having to sacrifice and be sacrificed after a thorough questioning, with the guiding issue of Abraham speaking the grim reality into existence. In the $T Y$ below, Abraham continues this thread by fully admitting the truth of Satan's lies. 
3.1.4 The River in the Road: Satan's Role in the Tested Faith in the TY On the third day, when Abraham lifted his head and saw the place from afar, the $T Y$ notes the incongruent amount of time for the short distance travelled, accounting for the lack of progress, by explaining that Satan, perturbed by being ignored, placed a river in Abraham's path. Abraham and retinue wade out up to their necks; Abraham cries out to God to spare him so he can do as he was commanded..$^{38}$ God removes the river. Undeterred, Satan again uses the words of Eliphaz from the book of Job (4:12):

Now a word was secretly brought to me (Job 4:12); that is, I have heard from behind the heavenly curtain that a lamb shall be sacrificed as a burnt offering instead of Isaac. ${ }^{39}$

Abraham, stalwart yet revealing as ever, tells Satan that it is a liar's penalty that even when he speaks truth, no one will believe him.

The process of faith is at play here, its contents in the willingness to fulfil commandments in the face of not only a physical obstacle, but the truth. Abraham beseeches the heavens, evoking the banner motif from $G R$ in asking God who will fulfil his commandments if either he or his son dies. This idea of sight aligns with the language of Genesis 22, where the term 'to see' (ראה, ra'ah) appears in various forms multiple times. ${ }^{40}$ Abraham cannot be the example of how God sees to or provides for those who heed his words if he is dead, which, curiously enough, are congruent with the implications of Satan's earlier remark to Isaac in the $T Y$ on the impossibility of studying law while dead: How is one to learn how to carry out the law when one's instruction is in breaking the law? To reformulate the question, how is the truth built upon a lie, and how can a lie be the truth?

Satan's river challenges Abraham, testing his resolution in order to discern his mettle, as if to suggest faith would be useless without these things obstacles, doubts and having one's own fears externalized, in this case manifest in an inquisitive, plainly speaking Satan. Satan's challenge is utterly indistinct from God's - for did not God agree to the wager? After and in these things, seeing events as good, bad, or evil is of no use because truth has many facets - it is relative - and not all of them are normative. Abraham conjures

38 Midrash Tanhuma-Yelammedenu $30 \mathrm{~b}, 144$.

39 Midrash Tanhuma-Yelammedenu $30 \mathrm{~b}, 145$.

40 For example, in the noun Moriah, which is used throughout the verse, and also in the famously enigmatic verse 14, where Abraham names the location of the sacrifice, יהוה יראה, or something "the Lord will see" or "the Lord will provide". 
images of deceit and misdirection, but his character here and in the other Midrashim directs him to consider what faith means, and whether it includes sacrifice. Notice that in the first 'gap' the analysis concerned the nature of God, while presently it centers around Abraham taking on the burden that he has accepted, and doing so by calling upon God to dry up the waters when death would have been an easy way to avoid filicide. Thus, it seems the more Satan pushes and questions, the stronger Abraham's resolve becomes.

Satan offers that a lamb will replace Isaac, which is the truth in the end. Yet this truth is most likely contingent upon Abraham being deterred or not. That is to say, if he quit, God would probably not have taken Isaac, while Abraham would still have maintained a place among the holy because he followed the law. However, to be able to offer the lamb in place of Isaac - even if it also served as a belated offering for the forgotten ritual at Isaac's weaning $(G R)-$ would surely be the greatest achievement, because in this case God is trusted to see to the situation. Although Abraham may be uncertain about the outcome, he is certain God will provide a solution, and this is a truth set against the truth that there may be honour in turning back when faced with death. Thus, just as this and the other Midrashim have brought out and fortified the 'gaps' in the biblical text, Satan within this form brings out and fortifies the 'gaps' in Abraham's spirituality.

4

\section{Conclusion: The New Akedah}

This chapter began by briefly detailing how traditional biblical commentaries treated the 'gaps' in the biblical text by hinting at the theological depth plumbed in Midrash. The strength of Midrash lies in its creative use of the text by inserting Satan into the narrative, causing one to rethink conceptions of faith. The Midrashic texts surveyed here in no small part call for a re-evaluation of the way we speak about sacrifice, and specifically how we view sacrifice through the lens of faith. The form of Midrash was a narrative that questioned the biblical text in order to explicate the minutia, and in this case, the devil was literally in the details. Relentlessly pursuing Abraham and Isaac, Satan opposed God, beseeching Abraham to uphold God's law, challenging Abraham to find and ground his faith through placing what were undoubtedly his own apprehensions right at his doorstep.

The power of the Midrashim is in their treatment of faith as dynamic process that resists being diluted into formulas and rudiments, seeing faith as a truth among truths. It asks one to doubt to believe, with doubt pointing at what one finds difficult, what one cherishes. Wenham gave the opening words 
of Genesis 22 a dampening function - they direct attention away from the intended sacrifice, focusing on whether Abraham will sacrifice. Abraham's trial is precisely not forgetting the importance of Isaac, and Satan potently reminds him in the Midrashim of his folly. Although Abraham confidently rebuffs Satan, his soul must have yearned and uttered a soft 'I know', for there would be no trial without recognition of the love he had for Isaac.

Satan, as he did throughout the Midrashim by opposing God, interrogates the value of the truth regarding faith. In $G R$, God's truth would be known through Abraham, but Satan inquires what type of truth is known through the sacrifice of innocents. Yet, just as Midrash asks the difficult questions, it draws back, giving no answers to the problem of Abraham's faith, for remaining steadfast - or faithful - is not an answer to the problem, but a tautology that can only be managed by Abraham. Consequently, perhaps the truth is in not believing the lie of fixed solutions, in removing the veil presented by the holy and admitting the gritty yet intoxicating allure of having one's eyes opened to the possibility of faith being a violent movement of the soul, in the suspension of belief and judgment.

It is recognized that the above reading is in many ways a radical reading of the Midrashim, but it is grounded in the view that Midrash itself is a radical manner of biblical interpretation, sacrificing certainty for the pursuit of what cannot be grasped. Endless discussion and interpretation of the Midrashim continually make Abraham's tale anew, and it is this remaking of tradition and viewing ancient texts through new eyes which keeps religion vibrant and relevant. Thus, the true import of the Akedah may be in the process, and in finding one's own manner of confronting reality. 